\title{
HLA-G levels in serum and plasma
}

\author{
N. Rudstein-Svetlicky ${ }^{1}$, R. Loewenthal ${ }^{1}$, V. Horejsi ${ }^{2}$ \& E. Gazit ${ }^{1}$ \\ 1 TissueTyping Laboratory, Sheba Medical Center, and Tel Aviv University, Tel Aviv, Israel \\ 2 Institute of Molecular Genetics, Prague, Czech Republic
}

\section{Key words}

ELISA; HLA-G; serum; plasma

\section{Correspondence \\ Ephraim Gazit, MD \\ Tissue Typing Laboratory \\ Sheba Medical Center \\ Ramat Gan \\ Israel \\ e-mail: egazit@post.tau.ac.il}

Received 24 May 2005; revised 18 August 2005; re-revised 25 September 2005 \& 02 November 2005; accepted 09 November 2005

doi: 10.1111/j.1399-0039.2005.00540.x

\begin{abstract}
HLA-G belongs to the non-classical HLA class-I family of genes presently designated as class-Ib genes. There are four membrane-bound (HLA-G1 to -G4) and three soluble forms (HLA-G5 to -G7) generated by alternative splicing of the primary transcript. HLA-G in the soluble form is found in the plasma, amniotic fluid, and cord blood of healthy individuals. Quantitative determination suggested that HLA-G levels are genetically controlled. While quantifying soluble HLA-G by ELISA, we observed that when plasma and serum levels were measured for the same individual, HLA-G plasma values were almost invariably higher than those from serum. Our results suggest that HLA-G is trapped and/or consumed during clot formation. The amount trapped within the clot is variable and inconsistent. To obtain values which reflect the true biological levels, it is therefore recommended that HLA-G should be determined in the plasma. If serum levels are determined, they should be compared with matched control sera. It should always be borne in mind that conclusions concerning sera levels might be erroneous, because the true plasma level of the protein can be significantly higher.
\end{abstract}

\section{Introduction}

HLA-G belongs to the non-classical HLA class-I family of genes presently designated as class-Ib genes [see review (1)]. It was first described as an HLA class-I gene that encodes a short cytoplasmic tail (2). Subsequently, it was reported that it is subjected to alternative splicing, yielding proteins with structures similar to HLA class-I and class-II antigens (3). It was found to be expressed mainly in placental tissue and in the thymus (4-8). A unique feature of HLA-G is the presence of a stop codon in exon 6 , which shortens its cytoplasmic protein tail (3-8). There are four membrane-bound (HLA-G1 to -G4) and three soluble forms (HLA-G5 to -G7) generated by alternative splicing of the primary transcript $(9,10)$. Limited polymorphism of HLA-G and expression restricted to the cytotrophoblast $(11,12)$ prompted the hypothesis that it provides the barrier that shields the fetus from the innate and/or acquired immunity of the mother. However, subsequent studies showed that this cannot be the exclusive mechanism of materno-fetal tolerance (13). Other studies showed that basal levels of HLA-G are transcribed in almost all tissues examined $(14,15)$. HLA-G in the soluble form is found in the plasma, amniotic fluid, and cord blood of healthy individuals (16). Quantitative determination of its levels suggested that the level is genetically controlled $(17,18)$.

Many studies were aimed at the determination of HLA-G in the plasma and/or serum of patients suffering from various diseases. Soluble HLA-G levels were determined in habitual abortions, in autoimmunity, in solid organ transplantation, and in various malignancies (19-30). In some studies, levels were found to be higher when compared with the control cohort, while in other studies levels were low when compared with controls. Because the enigma of HLA-G has not, as yet been solved, most studies were aimed at finding an explanation for its function in health and disease [16, 29, 31-34].

While quantifying soluble HLA-G by ELISA, we observed that when plasma levels were measured, HLA$G$ values were almost invariably higher than in random serum samples. Hence, the following studies were carried out to explore the reason for such variability. Our results suggest that HLA-G is trapped during clot formation. The amount trapped within the clot is variable and inconsistent. To obtain values which reflect the true biological levels, it is therefore recommended that HLA-G should 
be determined in the plasma. However, if only serum samples are available for a study, they should be compared with matched serum controls. Conclusions concerning HLA-G levels might be erroneous, because the true plasma level of the protein can be significantly higher.

\section{Materials and methods}

\section{Blood samples}

Blood samples were drawn from healthy volunteers after signing an informed consent form. Venous blood aliquotes from the same individual were placed into tubes containing dry EDTA, and glass tubes without anticoagulants. The latter were left at room temperature for $2-3 \mathrm{~h}$ for clot formation, and the serum was subsequently separated by centrifugation. EDTA-plasma and sera were kept frozen at $-30{ }^{\circ} \mathrm{C}$ until used.

\section{Recalcification of plasma}

Recalcification of EDTA plasma was carried out by the addition of $\mathrm{CaCl}_{2}(1 \mathrm{M}, 20 \mu \mathrm{l})$ to $1 \mathrm{ml}$ of plasma and incubated at $37^{\circ} \mathrm{C}$. If clot did not form, two drops of thrombine (Thrombine Topical-bovine, $200 \mu / \mathrm{ml}$ Armour Pharmaceutical Company, Kankakee, IL, USA) were added, and incubation continued until a clot was visible. The serum was subsequently separated by centrifugation.

\section{Tissue Plasminogen Activator treatment}

Recombinant tissue plasminogen activator (TPA) $(25 \mu \mathrm{l}$ of balanced salt solution containing $0.25 \mathrm{mg} / \mathrm{ml}$ TPA) was added to glass tubes containing $1 \mathrm{ml}$ of clotted whole blood and incubated in a water bath at $37^{\circ} \mathrm{C}$ for $30 \mathrm{~min}$. The tubes were shaken vigorously every $10 \mathrm{~min}$. Following incubation, the released serum was separated by centrifugation and kept frozen until used.

\section{ELISA procedure}

Microtiter trays (immunoplate, maxisorp, cat. no. 442404, Nunc, Roskilde, Denmark) were coated with the capturing antibody MEM-G/9 MoAb $(10 \mu \mathrm{g} / \mathrm{ml})$ diluted in phosphate buffered saline (PBS), $100 \mu \mathrm{l} /$ well. MEM-G/9 is a monoclonal antibody which binds to soluble HLA-G5 and to the cell bound and shedded HLA-G1 isoforms (34). Coating was carried out at $37^{\circ} \mathrm{C}$ for $2 \mathrm{~h}$. The trays were washed four times with PBS containing $0.2 \%$ Tween- 20 . Subsequently, blocking was performed for $2 \mathrm{~h}$ at $37^{\circ} \mathrm{C}$ with $2 \%$ bovine serum albumin in PBS. After four washings with cold $0.2 \%$ Tween-20 in PBS, the sera to be tested were added, in duplicate, $100 \mu \mathrm{l} /$ well diluted 1:2 in PBS and incubated overnight at $4{ }^{\circ} \mathrm{C}$. Dilution of 1:2 was used, because such dilutions were used in most other reports. In addition, dilution reduces the viscosity of the serum/ plasma and enhances specific binding. Following four washings with $0.2 \%$ Tween-20 in PBS, goat anti $\beta-2$ microglobulin/Horse-radish peroxidase (HRP) (Dako cat. no. P0174, Dako Denmark) diluted 1:500, $100 \mu \mathrm{l} /$ well were added and incubated at $37^{\circ} \mathrm{C}$ for $60 \mathrm{~min}$. This was followed by four washings with PBS/Tween-20. The enhancer, Envision System (Dako Envision system HRP, cat. no. K4002), diluted 1:15 in PBS, $100 \mu \mathrm{l} /$ well was added. Incubation was performed for $20 \mathrm{~min}$ at room temperature and was followed subsequently by five washings with $0.2 \%$ Tween-20 in PBS, and then $100 \mu$ of the substrate Tetra-methyl-benzidine (TMB) (Dako cat. no. S1599) was added. The trays were incubated in the dark at room temperature for 15-20 min. The reaction was terminated by the addition of $100 \mu \mathrm{l} \mathrm{HCl} 1 \mathrm{~N}$. The OD $(450 \mathrm{~nm})$ of the reactions was read by an ELISA reader and quantified by comparing the optical density to a reference serum whose concentration was determined by a calibration curve (Figure 1) (Recombinant HLA-G was kindly donated by Dr Nathalie Rouas-Freiss, Hospital St. Louis, Paris, France). The reference serum, which was obtained from a healthy individual, was used as the positive reference control in all determinations of HLA-G levels in subsequent experiments. To ascertain the fidelity of the ELISA test, we determined coefficient of variation (CV percentage $=$ standard deviation $/$ mean $\times 100$ ) for random high and low sHLA-G serum samples. Each sample was tested 20 times. The value of $\mathrm{CV}$ found for the high level serum was $14 \%$, and for the low serum level the CV was $6.9 \%$ (data not shown).

\section{Statistical analysis}

The data was analyzed by the paired Student $t$-test using the spss statistical package. $P$-values of $<0.0 .05$ are considered significant.

\section{Results and discussion}

Samples of EDTA plasma and serum separated from the same individual and prepared from the same aliquot of

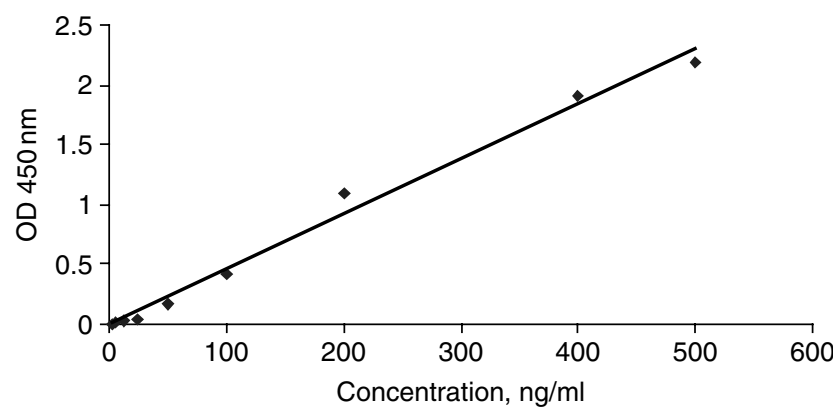

Figure 1 Calibration curve of HLA-G concentration. 
blood were tested for the level of HLA-G. All pairs of plasma and serum from a given individual were tested on the same day and on the same ELISA tray. As seen in Table 1 and Figure 2, significant differences were observed between the plasma and the serum samples. In 106 pairs of plasma-serum samples, the average level of HLA-G in the plasma was found to be $38.6 \pm 5.0 \mathrm{ng} / \mathrm{ml}$ compared with $25 \pm 4.6 \mathrm{ng} / \mathrm{ml}$ in the serum. These differences are highly significant $(P<0.001)$. To elucidate the reason for this phenomenon, we recalcified EDTA plasma converting the plasma into serum. Table 2 is a summary of representative experiments whereby 19 plasma samples were recalcified by the addition of $\mathrm{CaCl}_{2}$ and thrombine. The level of the plasma HLA-G was determined simultaneously with that of the serum. The level of HLA-G was reduced by clot formation suggesting that HLA-G is either trapped by the clot or consumed during clot formation (plasma level $34 \pm 8 \mathrm{ng} / \mathrm{ml} \quad$ vs recalcified plasma $6.3 \pm 3.1 \mathrm{ng} / \mathrm{ml} ; P<0.001)$. It should be noted that the addition of $\mathrm{CaCl}_{2}$ to serum samples did not reduce the measured values, i.e., $\mathrm{CaCl}_{2}$ by itself has no effect on this level (data not shown). To answer whether HLA-G is trapped or consumed during clot formation, clotted blood was incubated with TPA for $30 \mathrm{~min}$, and the resultant serum was separated form the partially dissolved clot.
The results of these experiments are summarized in Table 3. Results suggest that HLA-G is released from the clot, because its level is higher in the solubilized clot compared with the serum. However, levels did not reach initial plasma levels. This can be explained if some of the HLA-G protein is still trapped within the clot and/or consumed.

The interest in soluble MHC antigens was aroused many years ago. As early as 1992, an international workshop on soluble HLA was held with 15 laboratories actively participating in the endeavor (35). In this workshop, many questions were raised including technical and scientific aspects, but the main message was centered on the technical aspects of the procedure. One of the major conclusions was that to reach standardization, the same standard reference antigen, preferably produced by recombinant DNA technology, should be used by all investigators for the creation of a calibration curve.

The interest in the non-classical class-Ib HLA antigens is relatively recent. These antigens probably have important functional significance $(19-27,32)$. Soluble HLA-G is an important factor in host defense probably via the NK-KIR (KIR2DL4) and myeloid (ILT2/ILT4) receptors. This is, of course, aside from the functions of cell-bound HLA-G expressed on the trophoblast or epithelial thymus $(36,37)$. In addition, HLA-G was implicated as a possible

Table 1 Levels of sHLA-G in 50 consecutive* plasma and serum samples

\begin{tabular}{|c|c|c|c|c|c|}
\hline Sample & $\begin{array}{l}\text { sHLA-G in serum } \\
(\mathrm{ng} / \mathrm{ml})\end{array}$ & $\begin{array}{l}\text { sHLA-G in plasma } \\
(\mathrm{ng} / \mathrm{ml})\end{array}$ & Sample & $\begin{array}{l}\text { sHLA-G in serum } \\
(\mathrm{ng} / \mathrm{ml})\end{array}$ & $\begin{array}{l}\text { sHLA-G in plasma } \\
(\mathrm{ng} / \mathrm{ml})\end{array}$ \\
\hline 1 & 4 & 8 & 336 & 0 & 40 \\
\hline 3 & 46 & 50 & 337 & 44 & 46 \\
\hline 4 & 0 & 4 & 339 & 0 & 0 \\
\hline 6 & 2 & 10 & 344 & 0 & 2 \\
\hline 7 & 2 & 4 & 345 & 10 & 12 \\
\hline 11 & 26 & 44 & 347 & 0 & 0 \\
\hline 12 & 102 & 104 & 356 & 0 & 0 \\
\hline 15 & 8 & 8 & 357 & 0 & 3 \\
\hline 18 & 0 & 2 & 359 & 4 & 12 \\
\hline 20 & 0 & 2 & 363 & 28 & 32 \\
\hline 21 & 32 & 30 & 366 & 0 & 10 \\
\hline 23 & 0 & 0 & 368 & 5 & 16.6 \\
\hline 24 & 0 & 2 & 371 & 0 & 8 \\
\hline 26 & 2 & 2 & 409 & 0 & 138 \\
\hline 28 & 0 & 4 & 411 & 0 & 110 \\
\hline 316 & 26 & 30 & 412 & 0 & 32 \\
\hline 317 & 46 & 46 & 414 & 0 & 210 \\
\hline 318 & 21 & 46 & 417 & 0 & 44 \\
\hline 319 & 150 & 164 & 418 & 200 & 210 \\
\hline 321 & 0 & 32 & 420 & 148 & 140 \\
\hline 322 & 0 & 18 & 421 & 0 & 29.4 \\
\hline 324 & 80 & 126 & 423 & 150 & 158 \\
\hline 327 & 0 & 34 & 425 & 12 & 8 \\
\hline 332 & 30 & 40 & 426 & 72 & 142 \\
\hline 333 & 0 & 23.6 & 428 & 92 & 80 \\
\hline
\end{tabular}

*Altogether 106 samples of serum and plasma were studied. 


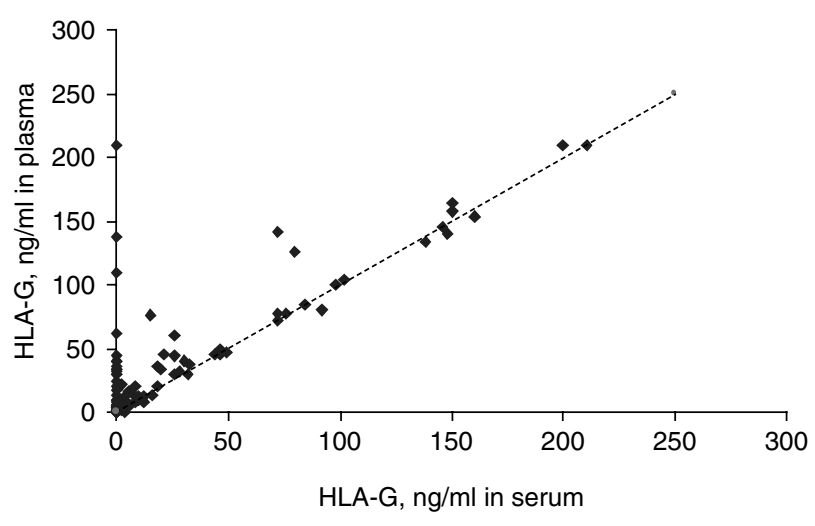

Figure 2 HLA-G levels in serum and plasma. Concentrations of plasma and serum are compared. Samples which are above the oblique line show differences between the serum and plasma levels.

agent by which tumors evade and escape the immune surveillance and enable the development of wide spread malignancy $(22,28-30)$. HLA-G might also be an important factor in the development of autoimmunity (38). Hence, measurement of the level of HLA-G in the body fluids is an intriguing and important challenge. The reports in the literature measuring the level of HLA-G in the blood are not restricted to either plasma or serum (16, 29, 31-33).

Some investigators have studied serum samples while others measured plasma levels. This creates uncertainty

Table 2 Levels of HLA G in recalcified plasma samples and original serum

\begin{tabular}{lcc}
\hline $\begin{array}{l}\text { Recalcified plasma levels* } \\
\text { (ng/ml) }\end{array}$ & Plasma levels $(\mathrm{ng} / \mathrm{ml})$ & Number of samples \\
\hline 0 & 0 & 337 \\
5 & 52 & 340 \\
0 & 44 & 342 \\
0 & 32 & 343 \\
0 & 20 & 346 \\
0 & 4 & 348 \\
3 & 14 & 349 \\
50 & 130 & 351 \\
0 & 42 & 352 \\
2 & 10 & 353 \\
7.2 & 28.8 & 354 \\
0 & 4.9 & 357 \\
5.6 & 13.2 & 359 \\
0 & 24 & 360 \\
0 & 10 & 363 \\
4.4 & 72 & 366 \\
5.6 & 18.6 & 368 \\
0 & 14 & 371 \\
37.6 & 108 & 28,901 \\
\hline
\end{tabular}

*See Materials and methods. with respect to the true blood level of this protein. In addition, the variations in blood levels are not exclusively the results of measurements of serum or plasma levels, but may also be due to the different protocols of ELISA used by the investigators. Different capturing monoclonal antibodies, incubation times, and washing efficiencies, in addition to differing sensitivities of the substrate and spectrophotometric reading wavelengths may all contribute to substantial differences in the results. For example, Yie et al. (32) found normal serum to be $93 \mathrm{ng} / \mathrm{ml}$ while Creput et al. found serum levels to be around $20 \mathrm{ng} / \mathrm{ml}$. Sebti et al. (29) used plasma to test for the levels of HLA-G and found it to be $18 \pm 9 \mathrm{ng} / \mathrm{ml}$ while Rebmann (16) studied plasma levels and found these were found to be $25 \mathrm{ng} / \mathrm{ml}$ in males and $20.1 \mathrm{ng} / \mathrm{ml}$ in females. Our results concerning mean plasma level $(38.6 \mathrm{ng} / \mathrm{ml})$ are somewhat higher than those reported by Rebmann and Sebti. This may be due to the different standards used for calibration. It supports the argument that an international reference standard, preferably commercially available, should be used by all those measuring the level (serum or plasma) of HLA-G.

Table 3 Levels of HLA G in serum following incubation of clotted blood with TPA

\begin{tabular}{|c|c|c|c|}
\hline $\begin{array}{l}\text { Level following incubation } \\
\text { of clotted blood with TPA } \\
\text { (ng/ml) }\end{array}$ & $\begin{array}{l}\text { Serum level } \\
(\mathrm{ng} / \mathrm{ml})\end{array}$ & $\begin{array}{l}\text { Plasma level } \\
\text { (ng/ml) }\end{array}$ & $\begin{array}{l}\text { Number of } \\
\text { samples }\end{array}$ \\
\hline 25.4 & 0 & 138 & 409 \\
\hline 2 & 0 & 110 & 411 \\
\hline 0 & 0 & 32 & 412 \\
\hline 13 & 0 & 210 & 414 \\
\hline 4 & 0 & 44 & 417 \\
\hline 202 & 200 & 210 & 418 \\
\hline 144 & 148 & 140 & 420 \\
\hline 0 & 0 & 29.4 & 421 \\
\hline 150 & 150 & 158 & 423 \\
\hline 8.8 & 8 & 12.4 & 425 \\
\hline 122 & 72 & 142 & 426 \\
\hline 78 & 92 & 80 & 428 \\
\hline 102 & 100 & 100 & 449 \\
\hline 0 & 0 & 30 & 451 \\
\hline 76 & 86 & 62 & 452 \\
\hline 96 & 86 & 84 & 454 \\
\hline 16 & 16 & 12 & 455 \\
\hline 15.2 & 18 & 19.2 & 457 \\
\hline 60 & 72 & 72 & 458 \\
\hline 6 & 0 & 6 & 460 \\
\hline 22 & 18 & 36 & 461 \\
\hline 16 & 8 & 20 & 463 \\
\hline 2 & 0 & 36 & 464 \\
\hline 0 & 0 & 6 & 467 \\
\hline 12 & 6 & 8 & 469 \\
\hline
\end{tabular}


In fact, a recent "wet workshop" was carried out in Essen in 2004 where the participants tested two monoclonal antibodies (MEM G/9 and 5A6G7) and two detecting antibodies, Anti $\beta 2 \mathrm{~m}$ and $w 6 / 32$ in an ELISA-based technique (39). The investigators reached the conclusion that the technique is reproducible and reliable. The monoclonal antibodies are specific in the determination of soluble HLA-G whether it is G1 or G5 isoforms. However, they did not test different sources of soluble HLA-G such as plasm $v s$ serum.

Our experiments address only one of these factors, namely the source of the blood product used for the assay. We show that different values are obtained when plasma or serum is measured. Such variations may lead to erroneous conclusions concerning HLA-G levels in health and disease.

The different levels can be explained if HLA-G is trapped in the blood clot, resulting in reduced serum levels. Reduced serum levels could also arise from decreased stability of HLA-G in the serum compared with plasma. However, the reduction of its level following recalcification of plasma is not a strong support for such a contention. The reduction is inconsistent and varies between individuals.

The lack of standardization creates uncertainty with respect to the biological importance of HLA G. It is therefore suggested that international collaborative studies should be carried out using common commercially available pure HLA-G as the calibration agent and common monoclonal antibodies and plasma as the substrate used for HLA-G determination.

\section{Acknowledgment}

This research was supported in part by a grant no. 652/04 to E. Gazit by the Israel Science Foundation (ISF).

\section{References}

1. Carosella ED, Moreau P, Le Maoult J, Le Discorde M, Dausset J, Rouas-Freiss N. HLA-G molecules: from maternal-fetal tolerance to tissue acceptance. Adv Immunol 2003: 81: 199-252.

2. Geraghty DE, Koller BH, Orr HT. A human major histocompatibility complex class I gene that encodes a protein with a shortened cytoplasmic segment. Proc Natl Acad Sci USA 1987: 84: 9145-9.

3. Ishitani A, Geraghty DE. Alternative splicing of HLA-G transcripts yields proteins with primary structures resembling both class I and class II antigens. Proc Natl Acad Sci USA 1992: 89: 3947-51.

4. Menier C, Riteau B, Dausset J, Carosella ED, Rouas-Freiss N. HLA-G truncated isoforms can substitute for HLA-G1 in fetal survival. Hum Immunol 2000: 61: 1118-25.
5. Moreau P, Rousseau P, Rouas-Freiss N, Le Discorde M, Dausset J, Carosella ED. HLA-G protein processing and transport to the cell surface. Cell Mol Life Sci 2002: 59: 1460-6.

6. Paul P, Cabestre FA, Le Gal FA et al. Heterogeneity of HLA-G gene transcription and protein expression in malignant melanoma biopsies. Cancer Res 1999: 59: 1954-60.

7. Rouas-Freiss N, Khalil-Daher I, Marchal-Bras Goncalves R, Menier C, Dausset J, Carosella ED. Role of HLA-G in maternal-fetal immune tolerance. Transplant Proc 1999: 31: 724-5.

8. Rouas-Freiss N, Khalil-Daher I, Riteau B et al. The immunotolerance role of HLA-G. Semin Cancer Biol 1999: 9: 3-12.

9. Moreau P, Dausset J, Carosella ED, Rouas-Freiss N. Viewpoint on the functionality of the human leukocyte antigen-G null allele at the fetal-maternal interface. Biol Reprod 2002: 67: 1375-8.

10. Paul P, Rouas-Freiss N, Moreau P et al. HLA-G-E-F preworkshop: tools and protocols for analysis of non-classical class I genes transcription and protein expression. Hum Immunol 2000: 61: 1177-95.

11. Gobin SJ, van den Elsen PJ. The regulation of HLA class I expression: is HLA-G the odd one out? Semin Cancer Biol 1999: 9: 55-9.

12. Gobin SJ, Keijsers V, Cheong C, van Zutphen M, Van den Elsen PJ. Transcriptional regulation of HLA-G. Transplant Proc 1999: 31: 1857-9.

13. Hviid TV, Hylenius S, Hoegh AM, Kruse C, Christiansen OB. HLA-G polymorphisms in couples with recurrent spontaneous abortions. Tissue Antigens 2002: 60: 122-32.

14. Kirszenbaum M, Moreau P, Gluckman E, Dausset J, Carosella E. An alternatively spliced form of HLA-G mRNA in human trophoblasts and evidence for the presence of HLA-G transcript in adult lymphocytes. Proc Natl Acad Sci USA 1994: 91: 4209-13.

15. Crisa L, McMaster MT, Ishii JK, Fisher SJ, Salomon DR. Identification of a thymic epithelial cell subset sharing expression of the class Ib HLA-G molecule with fetal trophoblasts. J Exp Med 1997: 186: 289-98.

16. Rebmann V, Pfeiffer K, Passler M et al. Detection of soluble HLA-G molecules in plasma and amniotic fluid. Tissue Antigens 1999: 53: 14-22.

17. Rebmann V, van der Ven K, Passler M, Pfeiffer K, Krebs D, Grosse-Wilde H. Association of soluble HLA-G plasma levels with HLA-G alleles. Tissue Antigens 2001: 57: 15-21.

18. Fournel S, Huc X, Aguerre-Girr M et al. Comparative reactivity of different HLA-G monoclonal antibodies to soluble HLA-G molecules. Tissue Antigens 2000: 55: 510-8.

19. Warner CM, Comiskey M, Clisham PR, Brenner CA. Soluble HLA-G (sHLA-G) a predictor of IVF outcome? J Assist Reprod Genet 2004: 21: 315-6.

20. Noci I, Fuzzi B, Rizzo R et al. Embryonic soluble HLA-G as a marker of developmental potential in embryos. Hum Reprod 2005: 20: 138-46, Epub 2004 Oct 21.

21. Creput C, Durrbach A, Charpentier B, Carosella ED, RouasFreiss N. [HLA-G: immunoregulatory molecule involved in allograft acceptance]. Nephrologie 2003: 24: 451-6.

22. Amiot L, Le Friec G, Sebti Y et al. HLA-G and lymphoproliferative disorders. Semin Cancer Biol 2003: 13: 379-85. 
23. Rebmann V, Regel J, Stolke D, Grosse-Wilde H. Secretion of sHLA-G molecules in malignancies. Semin Cancer Biol 2003: 13: $371-7$.

24. Hunt JS, Pace JL, Morales PJ, Ober C. Immunogenicity of the soluble isoforms of HLA-G. Mol Hum Reprod 2003: 9: 729-35.

25. Le Bouteiller P, Pizzato N, Barakonyi A, Solier C. HLA-G, pre-eclampsia, immunity and vascular events. $J$ Reprod Immunol 2003: 59: 219-34.

26. Wiendl H, Mitsdoerffer M, Hofmeister V et al. The nonclassical MHC molecule HLA-G protects human muscle cells from immune-mediated lysis: implications for myoblast transplantation and gene therapy. Brain 2003: 126: 176-85.

27. Rouas-Freiss N, Paul P, Dausset J, Carosella ED. HLA-G promotes immune tolerance. $J$ Biol Regul Homeost Agents 2000: 14: 93-8.

28. Singer G, Rebmann V, Chen YC et al. HLA-G is a potential tumor marker in malignant ascites. Clin Cancer Res 2003: 9: 4460-4.

29. Sebti Y, Le Friec G, Pangault C et al. Soluble HLA-G molecules are increased in lymphoproliferative disorders. Hum Immunol 2003: 64: 1093-101.

30. Rouas-Freiss N, Moreau P, Menier C, Carosella ED. HLA-G in cancer: a way to turn off the immune system. Semin Cancer Biol 2003: 13: 325-36.

31. Hviid TV, Rizzo R, Christiansen OB, Melchiorri L, Lindhard A, Baricordi OR. HLA-G and IL-10 in serum in relation to HLA-G genotype and polymorphisms. Immunogenetics 2004: 56: 135-41, Epub 2004 May 7.
32. Yie SM, Li LH, Li YM, Librach CL. HLA-G protein concentrations in maternal serum and placental tissue are decreased in preeclampsia. Am J Obstet Gynecol 2004: 191: 525-9.

33. Hackmon R, Hallak M, Krup M et al. HLA-G antigen and parturition: maternal serum, fetal serum and amniotic fluid levels during pregnancy. Fetal Diagn Ther 2004: 19: 404-9.

34. Menier C, Saez B, Horejsi V et al. Characterization of monoclonal antibodies recognizing HLA-G or HLA-E: new tools to analyze the expression of nonclassical HLA class I molecules. Hum Immunol 2003: 64: 315-26.

35. Pouletty P, Ferrone S, Amesland F et al. Summary report from the first international workshop on soluble HLA antigens. Paris, August 1992. Tissue Antigens 1993: 42: 45-54.

36. Houlihan JM, Biro PA, Harper HM, Jenkinson HJ, Holmes CH. The human amnion is a site of MHC class Ib expression: evidence for the expression of HLA-E and HLA-G. J Immunol 1995: 154: 5665-74.

37. Mallet V, Blaschitz A, Crisa L et al. HLA-G in the human thymus: a subpopulation of medullary epithelial but not CD83(+) dendritic cells expresses HLA-G as a membranebound and soluble protein. Int Immunol 1999: 11: 889-98.

38. Gazit E, Slomov Y, Goldberg I, Brenner S, Loewenthal R. HLA-G is associated with pemphigus vulgaris in Jewish patients. Hum Immunol 2004: 65: 39-46.

39. Rebmann V, Lemaoult J, Rouass-Freiss N, Carosella ED, Grosse Wilde H. Report of the wet workshop for quantification of soluble HLA-Gin Essen, 2004. Hum Immunol 2005: 66: $853-63$ 